\title{
A quantitative SWOT analyses of key aquaculture players in Africa
}

\author{
Adeleke Babatunde $^{1} \cdot$ Robertson-Andersson Deborah $^{1} \cdot$ Moodley Gan ${ }^{1}$. \\ Taylor Simon ${ }^{2}$
}

Received: 20 November 2020 / Accepted: 3 May 2021/ Published online: 21 May 2021

(C) The Author(s) 2021

\begin{abstract}
Africa's contribution to world aquaculture production in 2018 is still insignificant $(2,196,600$ tons; $\sim 2.7 \%$ ) albeit significantly increasing with larger-scale investments in Egypt (1,561,457 tons), Nigeria (291,233 tons), and Uganda (103,737 tons) producing substantial quantities $(91 \%)$ of the total fish production from the region. The quantitative SWOT technique and the multi-attribute decision-making method (MADM) were used to determine and compare aquaculture performance in production, technology, market, policies, and framework among Egypt, Nigeria, Uganda, and South Africa. Factors such as the adoption of new technologies used in the formulation and production of aquafeed (i.e., extruded feed and sinking feed), adoption of best farm management practices, commercialization of aquaculture, growing demand-supply gap due to high per capita consumption of fish, and government's prioritization of aquaculture industry development through the creation of enabling environment for private sector participation were key strengths and opportunities identified among the leading players. The quantified SWOT shows Egypt exhibited aquaculture development strengths and opportunities; Nigeria has aquaculture development opportunities but weak in competitive strengths, while Uganda and South Africa both possess low, competitive strengths and being faced with threats. Capitalizing on the available opportunities and critical success factors of the leading aquaculture players in Africa, this analysis highlights strategic actions that could boost the development of aquaculture in South Africa. The quantified SWOT analysis was used to determine the competitive position of the aquaculture sectors of the compared countries and can be used as a basis for aquaculture policies and roadmaps.
\end{abstract}

Keywords Quantified SWOT · Aquaculture $\cdot$ Egypt $\cdot$ Nigeria $\cdot$ Uganda $\cdot$ South Africa

Handling Editor: Gavin Burnell

Adeleke Babatunde

tundeadeleke@gmail.com

1 Marine Biology, School of Life Sciences, University of KwaZulu-Natal, Westville, Durban, KZN, South Africa

2 RLEDI-GSBL, University of KwaZulu-Natal, Westville, Durban, KZN, South Africa 


\section{Introduction}

Africa's contribution to global aquaculture production in 2018 was estimated at 2.196 million tons representing an insignificant $2.67 \%$ and primarily dominated by the production of freshwater finfish (FAO 2020). This represents almost 20-fold production increase from 110,200 to $2,196,000$ tons with a compound annual growth rate (CAGR) of $15.55 \%$. The leading producers, Egypt (1,561,457 tons), Nigeria (291,233 tons), and Uganda (103,737 tons), account for about $91 \%$ of total aquaculture production of the region (FAO 2020; Halwart 2020). The growth in aquaculture production was due to the advent and intensification of private sector controlled small and medium scale enterprises (SMEs) (Satia 2010). Also, the development of big commercial enterprises mostly stimulated by the combination of burgeoning public support, expertise, foreign direct investment, interest in aquaculture, global awareness raised through the NEPAD Fish for All Summit of 2005 as well as the implementation of the FAO Special Program for Aquaculture Development in Africa (SPADA) contributed to aquaculture growth (Satia 2010).

Most of the production (99\%) is from inland freshwater systems and primarily dominated by the culture of indigenous and abundant species of tilapia and African catfish. At the same time, mariculture only contributes a meagre $1 \%$ to total production quantity, although it is an emerging and promising subsector (Satia 2010; FAO 2016, 2018). New aquaculture production systems such as tanks and cages were introduced, as well as the improvement of current production systems, i.e., recirculating aquaculture system (RAS) and aquaponics (Satia 2011). The aquaculture sector employs about 6.2 million people in Africa with a large share of the employees being women in large scale commercial farms (Satia 2016). Therefore, the aquaculture sector has the potential to significantly contribute to food security, reduce unemployment rates and economic development of Africa.

Many governments in Africa have started realizing the importance of creating enabling business environment by taking steps such as expediting, coordinating and adopting policy reforms in order to create a conducive environment for business to thrive albeit, not directly connected with aquaculture. However, it has ripple effects on the sector (Satia 2011). Some countries have developed and adopted aquaculture-centered policies and strategic framework as a roadmap to guide development (Jamu et al. 2012). Provision of soft credits and incentives were facilitated by few governments nonetheless access to affordable credit, sufficient quality and quantity of inputs, land ownership and the disconnect between farmers, researchtechnology development and extension services still constitute major constraints to the development and intensification of the aquaculture sector (Satia 2010; Jamu and Brummett 2004). Existing biotechnical, economic and institutional challenges, which include the absence of national policies to guide aquaculture development, unfriendly investment policies, the absence of linkages between farmers, research/technology development and extension, and unfavorable investment climates, are currently being addressed in many African countries.

A Strengths, Weaknesses, Opportunities and Threats (SWOT) analysis is an informative tool frequently used to assess strengths and weaknesses (internal factors) of a company or industry (in this case, the aquaculture industry of key African players) and the potential opportunities and threats (external factors) of the operating environment that can have an impact on the sector such as consumers, government policy, and markets community pressures (Radheyshyam 2001; Görener et al. 2012; Rimmer et al. 2013). A SWOT analysis provides a useful framework that can help to identify problems, making decisions, planning, implementation of appropriate technology, and precautionary measures to be taken to accelerate 
sustainable aquaculture production (Radheyshyam 2001). The aim of analyzing external opportunities and threats is to evaluate the opportunities that can be harnessed and to avoid threats from an uncontrollable external environment. The analysis of internal strengths and weaknesses is carried out to appraise the internal activities of a sector (Chang and Huang 2006). The traditional SWOT method despite its advantages has several flaws due to the production of a partial and imprecise list of factors; depends on subjective opinion; and lack prioritization of the importance of each SWOT factor (Phadermrod et al. 2016). The quantified SWOT analytical approach adopts the concept of multiple-attribute decision-making (MADM), which uses a multi-layer scheme to simplify complicated problems. It is, therefore, able to carry out SWOT analyses on many objects simultaneously (Chang and Huang 2006). The Quantified SWOT does not only enhance the AHP-SWOT method but also develops the method using the Grand Strategy Matrix (GSM). The organizations are placed in the four quadrants of the coordinate according to their categories (Fig. 1). The ordinate represents the external environment (opportunities and threats), while the abscissa represents the internal environment (strengths and weaknesses).

Qualitative SWOT analyses in recent years have been applied to marine and freshwater fisheries in peer-reviewed journals (Stead 2005; Çelik et al. 2012; Panigrahi and Mohanty 2012; Glass et al. 2015) and more prevalent in aquaculture (Ahmed and Luong-Van 2009; Bolton et al. 2009; Cowx et al. 2010; Garza-Gil et al. 2009; Rimmer et al. 2013); however, there is a limited or no application of quantitative SWOT analytical approach to fisheries and aquaculture studies at the time of this study. Therefore, this study aims to compare the aquaculture sector of leading players in Africa (Egypt, Nigeria, and Uganda) vis-à-vis South Africa using the quantified SWOT analytical method. This study thus presents a novel quantitative analysis of aquaculture development, a foundation for future quantitative analysis
Opportunities
Quadrant II
1. Market development
2. Market penetration
3. Product development
4. Horizontal integration
5. Divestiture
6. Liquidation

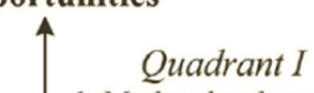
1. Market development
2. Market penetration
3. Product development
4. Forward integration
5. Backward integration
6. Horizontal integration
7. Concentric diversification

\section{Quadrant III}

\section{Retrenchment \\ 2. Concentric diversification \\ 3. Horizontal diversification \\ 4. Conglomerate diversification \\ 5. Divestiture \\ 6. Liquidation}
Strengths

\section{Quadrant IV}
1. Concentric diversification
2. Horizontal diversification
3. Conglomerate diversification
4. Joint Venture

\section{Threats}

Weaknesses

Fig. 1 Quantified SWOT analysis and strategic matrix (source: Chang and Huang (2006)) 
in fisheries and aquaculture, and to guide policymakers with better strategies for policy formulation and management.

\section{Methodology}

The quantified SWOT analysis used in business management was adapted to analyze the aquaculture sectors of key players in Africa by combining SWOT with multi-attribute decisionmaking (MADM) within a comprehensive analytical framework in order to assess, compare and quantify cross-country aquaculture sectors based on predefined evaluation criteria. This study adopts a 4-step MADM additive valuation method proposed by Chang and Huang (2006), to assess and compare countries' aquaculture sector performances quantitatively. The four facets of the selected MADM tool include "alternatives" regarding key aquaculture countries being compared, "criteria" referring to the predefined evaluation criteria, and "performance" which refers to progress made by countries on key factors as highlighted in Fig. 2. In light of those, as mentioned earlier, the analytical approach for this study consists of the following steps:

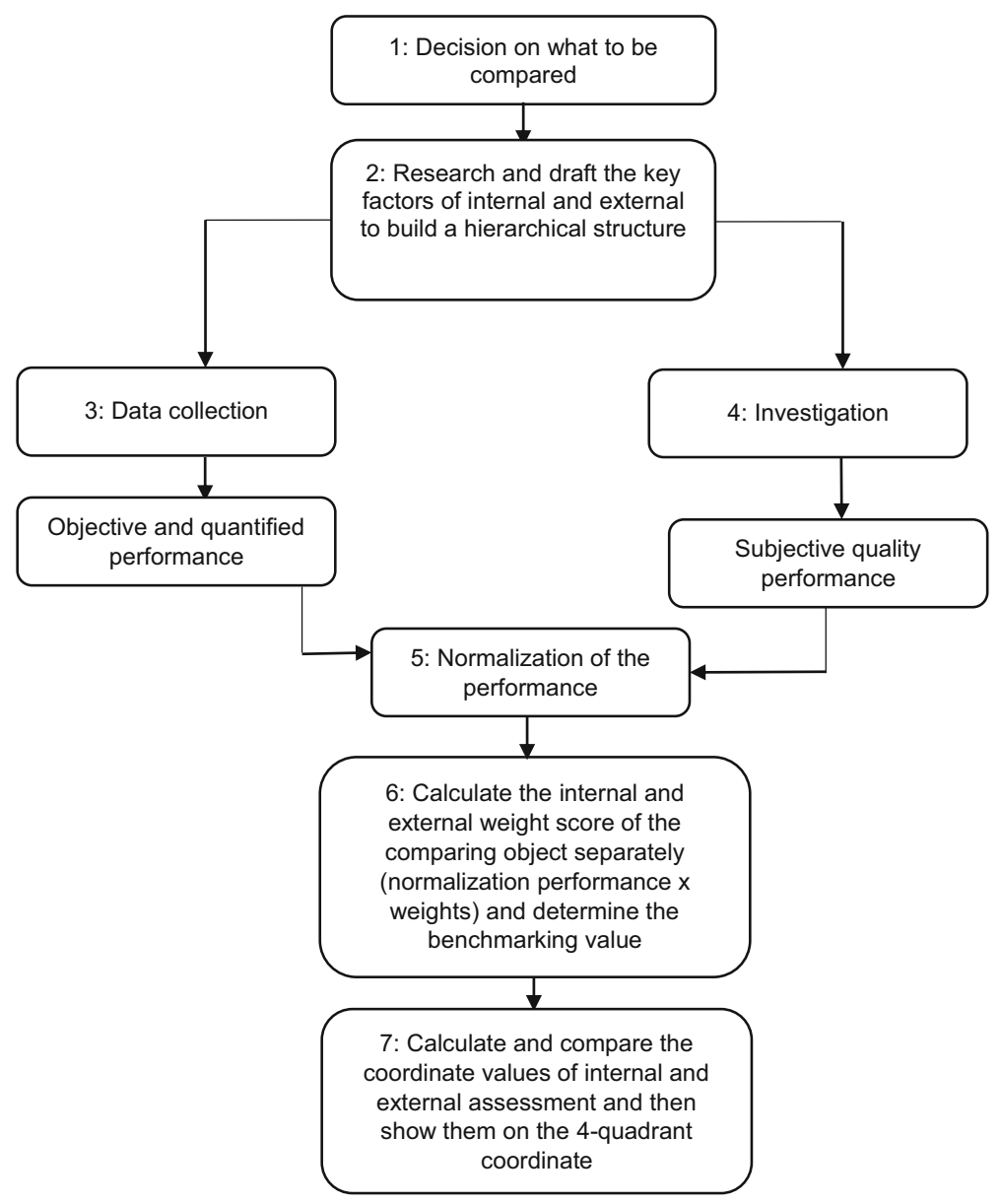

Fig. 2 Flowchart of quantified SWOT analysis pattern (adapted from Chang and Huang (2006)) 


\section{Determination of assessment criteria}

Assessment criteria for the internal factors (strengths and weaknesses) and external factors (threats and opportunities) responsible for the development of the aquaculture sector of each country to build a structure were determined.

The key factors for the internal assessment analysis were listed as (I) production output, (II) diversity of cultured species, (III) production technology, (IV) type of aquaculture, freshwater and/ marine, (V) seed production, (VI) cost of feed, (VII) arable land, (VIII) inland water resources (IX) coastal water resources, (X) labor employed, (XI) credit and insurance access, (XII) research and development, (XIII) extension services, and (XIV) best management practices (Table 1).

The factors for the external assessment analysis are broadly grouped into the economic environment; political environment, and geographic location (Table 2). Thus, the external criteria details are (I) local fish demand, (II) export, (III) per capita fish consumption, (IV) market size, (V) policies, plans, legislation, and aquaculture development approaches, (VI) registrations and permits, and (VII) strength and weakness of geographic location.

\section{Data collection}

The objective and performance data for the internal and external assessment factors of the key aquaculture players in Africa were collected (Tables 1 and 2) as reviewed from available published information on each country: Egypt ( El-Sayed 2007; Nassr-Alla 2008; El-Sayed 2013; Nasr-Allah et al. 2014; El-Sayed et al. 2015; Soliman and Yacout 2016;), Nigeria (Fagbenro and Adebayo 2005; FAO 2007-2020; Oyakhilomen and Zibah 2013; Ozigbo et al. 2014; Adewumi 2015), Uganda (FAO 2004-2020; FAO, 2011; Jamu et al. 2012; Rutaisire et al. 2017), and South Africa ( Britz and Venter 2016; DAFF 2017; FAO 2010-2020b; FAO 2004-2020).

Table 1 Internal assessment score of key aquaculture players in Africa (El-Sayed 2013; Ozigbo et al. 2014; Soliman and Yacout 2016; Fagbenro and Adebayo 2005; Adewumi 2015; Nassr-Alla 2008; Britz and Venter 2016; DAFF 2017; FAO, 2011; Rutaisire et al. 2017; El-Sayed 2013; Nasr-Allah et al. 2014; Oyakhilomen and Zibah 2013; Jamu et al. 2012; FAO 2010-2020b; El-Sayed et al. 2015; "Leaf-nosed bat" 2009; FAO 2004-2020, 2007-2020)

\begin{tabular}{|c|c|c|c|c|c|c|c|}
\hline \multicolumn{2}{|c|}{ Internal assessment of key factors } & \multirow[t]{2}{*}{ Units } & \multirow[t]{2}{*}{ Polarity } & \multicolumn{4}{|l|}{ Countries } \\
\hline & & & & Egypt & Nigeria & Uganda & South Africa \\
\hline 1 & Production output & Tons & + & $1,451,841$ & 296,071 & 112,343 & 5185 \\
\hline 2 & Species diversity & No. & + & 16 & 5 & 5 & 20 \\
\hline 3 & Production technology & 5 scales & + & 2 & 3 & 2.5 & 4.5 \\
\hline 4 & $\begin{array}{l}\text { Type of aquaculture } \\
\text { (freshwater and/marine) }\end{array}$ & 5 scales & + & 3 & 2 & 1.5 & 4.5 \\
\hline 5 & Seed production & 5 scales & + & 4.57 & 1.02 & 0.39 & 0.03 \\
\hline 6 & Cost of feed & Cost/tone (\$) & - & 870 & 1200 & 840 & 1100 \\
\hline 7 & Land (arable) & $\%$ of area & + & 2.8 & 37.3 & 34.3 & 9.9 \\
\hline 8 & Inland water resources & $\%$ of area & + & 0.632 & 1.4 & 15.39 & 0.38 \\
\hline 9 & Coastal water resources & Coastline & + & 2450 & 853 & 0 & 2798 \\
\hline 10 & Labor employed & No. & + & 580,000 & 475,000 & 24,434 & 3826 \\
\hline 11 & Credit and insurance access & 5 scales & + & 0.75 & 1.50 & 1.75 & 2.75 \\
\hline 12 & Research and development & 5 scales & + & 4.50 & 4.50 & 2.50 & 4.00 \\
\hline 13 & Extension services & 5 scales & + & 1.25 & 2.45 & 3.25 & 1.25 \\
\hline 14 & Best management practices & 5 scales & + & 2.25 & 3.25 & 3.0 & 4.50 \\
\hline
\end{tabular}

Polarity: “+” = benefit criteria; “-” = cost criteria 
Table 2 External assessment score of key aquaculture players in Africa (El-Sayed 2007; Ozigbo et al. 2014; Soliman and Yacout 2016; Fagbenro and Adebayo 2005; Adewumi 2015; Nassr-Alla 2008; Britz and Venter 2016; DAFF 2017; FAO, 2011; Rutaisire et al. 2017; El-Sayed 2013; Nasr-Allah et al. 2014; Oyakhilomen and Zibah 2013; Jamu et al. 2012; FAO 2010-2020b; El-Sayed et al. 2015; "Leaf-nosed bat" 2009; FAO 2004-2020, 2007-2020)

\begin{tabular}{|c|c|c|c|c|c|c|}
\hline $\begin{array}{l}\text { External assessment of } \\
\text { key factors }\end{array}$ & \multirow[t]{2}{*}{ Units } & \multirow[t]{2}{*}{ Polarity } & \multicolumn{4}{|l|}{ Countries } \\
\hline & & & Egypt & Nigeria & Uganda & South Africa \\
\hline 1 Local demand & Tones & + & $1,700,000$ & $3,000,000$ & 525,000 & 342,000 \\
\hline 2 Export & Tons & + & 15,810 & 30,000 & 20,000 & 1400 \\
\hline 3 Per capital consumption & $\mathrm{kg} /$ person & + & 16 & 13.3 & 12.5 & 7.5 \\
\hline 4 Trade value & USD\$ & + & $2,180,000,000$ & $1,300,000,000$ & $250,000,000$ & $48,200,000$ \\
\hline $\begin{array}{l}5 \text { Policies, plans, } \\
\text { legislation, } \\
\text { and aquaculture } \\
\text { development } \\
\text { approaches }\end{array}$ & 5 scales & + & 4.17 & 3.5 & 3 & 4.83 \\
\hline 6 Registrations and permit & 5 scales & + & 3 & 4 & 3.5 & 1 \\
\hline 7 Geographical location & 5 scales & + & 2 & 4.5 & 3.5 & 3 \\
\hline
\end{tabular}

Polarity: “+” = benefit criteria; “-” = cost criteria

\section{Performance normalization}

This is the definition of the weighted score for the identified internal and external factors (Tables 1 and 2) and performance scoring system (performance normalization) for the aquaculture sector of the key players in Africa. The key factors' performance was separated into two: quantified and qualified performance. The quantified performance were actual statistics, while the qualified performance were subjective scores of the internal and external factors ranging from 1 to 5 points (the higher the score, the better) (Tables 1, 2, and 3). The quantified and qualified performances were unified using the method of normalization as proposed by Chang and Huang (2006) (see Tables 4 and 5).

Benefit-criteria normalization (the higher, the better)

$$
r_{i j}=\frac{p_{i j}}{\max _{j} p_{i j}}, \forall_{j}
$$

where:

$r_{i j} \quad$ normalized performance of the $j$ th score

$p_{i j} \quad$ performance of the $j$ th score

$\max p_{i j} \quad$ highest performance of the $j$ th score

e.g., (2) diversity of culture species (Table 1)

$\mathrm{P} 1=16, \mathrm{P} 2=5, \mathrm{P} 3=5, \mathrm{P} 4=20$ (see Table 1 , row 2 )

$r_{i j}$ (benefit-criteria normalization) $=p_{i j}(16) / \max p_{i j}(20)$

$\mathrm{r} 1=16 / 20=0.800 ; \mathrm{r} 2=5 / 20=0.250 ; \mathrm{r} 3=5 / 20=0.250 ;$ and $\mathrm{r} 4=20 / 20=1.000$ (see

Table 4, row 2) 


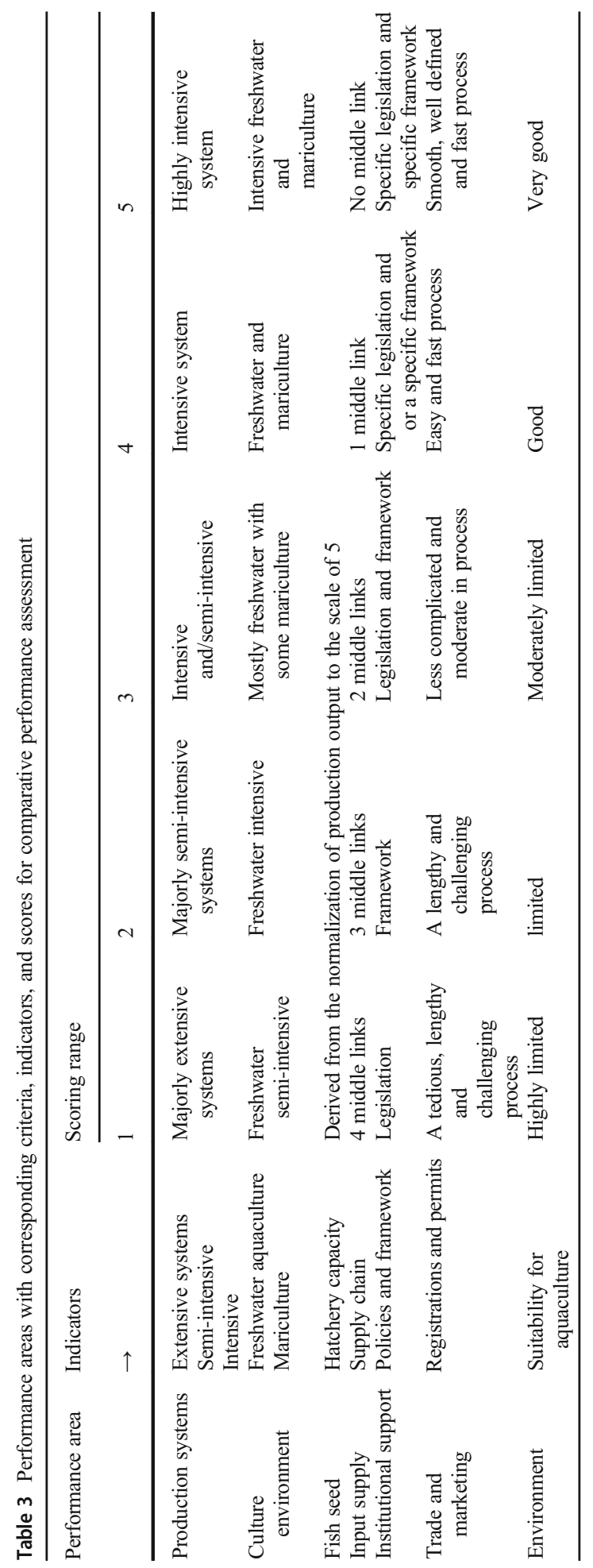


Table 4 Internal assessment weighted average score of key aquaculture players in Africa

\begin{tabular}{|c|c|c|c|c|c|c|c|}
\hline \multicolumn{2}{|c|}{ Internal assessment key factors } & \multirow[t]{2}{*}{ Units } & \multirow[t]{2}{*}{ Polarity } & \multicolumn{4}{|c|}{ Countries } \\
\hline & & & & Egypt & Nigeria & Uganda & South Africa \\
\hline 1 & Production output & tons & + & 1.000 & 0.204 & 0.077 & 0.004 \\
\hline 2 & Species diversity & No. & + & 0.800 & 0.250 & 0.250 & 1.000 \\
\hline 3 & Production technology & 5 Scales & + & 0.444 & 0.667 & 0.556 & 1.000 \\
\hline 4 & $\begin{array}{l}\text { Type of aquaculture } \\
\text { (freshwater and/marine) }\end{array}$ & 5 Scales & + & 0.667 & 0.444 & 0.333 & 1.000 \\
\hline 5 & Seed production & Units & + & 1.000 & 0.224 & 0.086 & 0.006 \\
\hline 6 & Cost of feed & Cost in rands & - & 0.966 & 0.700 & 1.000 & 0.764 \\
\hline 7 & Land (Arable) & $\%$ of area & + & 0.075 & 0.091 & 1.000 & 0.025 \\
\hline 8 & Inland water resources & $\%$ of area & + & 0.041 & 0.091 & 1.000 & 0.025 \\
\hline 9 & Coastal water resources & Coastline & + & 0.876 & 0.305 & 0.000 & 1.000 \\
\hline 10 & Labor employed & No. & + & 1.000 & 0.819 & 0.042 & 0.007 \\
\hline 11 & Credit and insurance access & 5 scales & + & 0.273 & 0.545 & 0.636 & 1.000 \\
\hline 12 & Research and development & 5 scales & + & 1.000 & 1.000 & 0.556 & 0.889 \\
\hline 13 & Extension services & 5 scales & + & 0.385 & 0.754 & 1.000 & 0.385 \\
\hline 14 & Best management practices & 5 scales & + & 0.500 & 0.722 & 0.667 & 1.000 \\
\hline \multicolumn{4}{|c|}{ Weighted average } & 0.645 & 0.550 & 0.508 & 0.596 \\
\hline
\end{tabular}

Cost-criteria normalization (the lower, the better)

$$
r_{i j}=\frac{\min _{j} p_{i j}}{p_{i j}}, \forall_{j}
$$

where:

$r_{i j} \quad$ normalized performance of the $j$ th score

$p_{i j} \quad$ performance of the $j$ th score

$\min p_{i j} \quad$ lowest performance of the $j$ th score

e.g., (6) cost of feed (USD/ton) (Table 1)

$\mathrm{P} 1=870 ; \mathrm{P} 2=1200 ; \mathrm{P} 3=840: \mathrm{P} 4=1100$ (see Table 1, row 6)

$r_{i j}($ cost-criteria normalization $)=\min p_{i j}(840) / p_{i j}(870)$

Table 5 External assessment weighted average score of key aquaculture players in Africa

\begin{tabular}{|c|c|c|c|c|c|c|c|}
\hline \multirow{2}{*}{\multicolumn{2}{|c|}{ External assessment key factors }} & \multirow[t]{2}{*}{ Units } & \multirow[t]{2}{*}{ Polarity } & \multicolumn{4}{|c|}{ Countries } \\
\hline & & & & Egypt & Nigeria & Uganda & South Africa \\
\hline 1 & Local demand & Tones & + & 0.567 & 1.000 & 0.175 & 0.114 \\
\hline 2 & Export & Tons & + & 0.527 & 1.000 & 0.667 & 0.047 \\
\hline 3 & Per capital consumption & $\mathrm{kg} /$ person & + & 1.000 & 0.858 & 0.806 & 0.387 \\
\hline 4 & Trade value & USD\$ & + & 1.000 & 0.596 & 0.115 & 0.022 \\
\hline 5 & $\begin{array}{l}\text { Policies, plans, legislation, and } \\
\text { aquaculture development approaches }\end{array}$ & 5 scales & + & 0.863 & 0.724 & 0.621 & 1.000 \\
\hline 6 & Registrations and permit & 5 scales & + & 0.750 & 1.000 & 0.875 & 0.250 \\
\hline 7 & Geographical location & 5 scales & + & 0.444 & 1.000 & 0.778 & 0.667 \\
\hline \multicolumn{4}{|c|}{ Weighted average value } & 0.736 & 0.871 & 0.537 & 0.342 \\
\hline
\end{tabular}


$\mathrm{r} 1=840 / 870=0.966 ; \mathrm{r} 2=840 / 1200=0.700 ; \mathrm{r} 3=840 / 840=1.000 ;$ and $\mathrm{r} 4=840 / 1100=$ 0.764 (see Table 4, row 6)

\section{Determination of benchmarking and SWOT coordinate values}

The final step was the calculation and comparison of the SWOT coordinate values of the internal and external assessment using total weighted performances. The internal and external weighted score of the compared countries were calculated separately, and the benchmarking values were determined by taking the mean weighted score in line with Chang and Huang (2006) (see Tables 4, 5, and 6).

The benchmarking values for the internal and external SWOT assessment factors of the compared countries (Egypt, Nigeria, Uganda, and South Africa) were subtracted from the mean score of the internal and external factors of each country. The obtained values were used to plot the coordinate values of the compared countries in the SWOT analysis matrix (Table 6).

$$
\begin{array}{cc}
\text { IC j }=\text { I j-I B } & \mathrm{j}=1,2 \ldots, n \\
\text { EC j }=\text { E j-E B } & j=1,2 \ldots, n
\end{array}
$$

where:

IC $\mathrm{j}$ the internal assessment coordinate value of the $j$ th country.

I j internal assessment score of the $j$ th country.

I B benchmarking the value of the internal assessment.

$\mathrm{EC} \mathrm{j}$ the external assessment coordinate value of the $j$ th country.

$\mathrm{E} \mathrm{j}$ external assessment score of the $j$ th country.

E B benchmarking the value of the external assessment.

$$
\begin{array}{r}
-1 \leq \mathrm{IC} \mathrm{j} \leq+1 \\
-1 \leq \mathrm{EC} \mathrm{j} \leq+1 .
\end{array}
$$

\begin{tabular}{|c|c|c|c|c|}
\hline Egypt & Nigeria & Uganda & $\begin{array}{l}\text { South } \\
\text { Africa }\end{array}$ & $\begin{array}{l}\text { Benchmarking } \\
\text { value }^{\mathrm{a}}\end{array}$ \\
\hline $0.645 \pm 0.36$ & $0.550 \pm 0.30$ & $0.508 \pm 0.38$ & $0.596 \pm 0.45$ & 0.568 \\
\hline 0.077 & -0.017 & -0.060 & 0.028 & \\
\hline $0.736^{*} \pm 0.23$ & $0.871^{*} \pm 0.17$ & $0.537 \pm 0.29$ & $0.342 \pm 0.36$ & 0.622 \\
\hline 0.114 & 0.250 & -0.084 & -0.279 & \\
\hline
\end{tabular}

Table 6 SWOT assessment weighted mean $( \pm \mathrm{SD})$ and coordinate values for the compared countries (Egypt, Nigeria, Uganda, and South Africa). * denotes significant difference $(p<0.05)$

Countries

${ }^{a}$ Mean value

${ }^{\mathrm{b}}$ Coordinate value $=$ weighted average value - benchmarking value 


\section{Randomization and variability of SWOT assessment factors}

The benchmarking values (internal and external) were subtracted from the objective and subjective normalized scores of the internal and external SWOT assessment factors (Tables 4 and 5). Subsequently, the derived internal and external SWOT values of the subjective performance were randomized 1000 times to minimize bias, while the objective performance was fixed. The mean values obtained were used to determine the effects of the SWOT assessment factors variability on the SWOT quadrant.

\section{Statistical analysis}

The internal and external SWOT assessment weighted mean values of Egypt, Nigeria, Uganda, and South Africa were statistically compared using a one-way analysis of variance (ANOVA) after testing for normality of distribution and equality of variance of tested variables. Fisher's LSD pairwise comparison test was used to determine the significant difference between the weighted mean values of the compared countries at 95\% confidence limits using IBM SPSS 25 statistical software program.

\section{Results}

The benchmarking value for the internal assessment of aquaculture sectors of Egypt, Nigeria, Uganda, and South Africa is 0.568, while the benchmarking value for the external assessment of these sectors is 0.622 (Table 6). The coordinate values of internal assessment of Egypt, Nigeria, Uganda, and South Africa are 0.077, $-0.017,-0.060$, and 0.028, while the coordinate values of their external assessment are $0.114,0.250,-0.084$, and -0.279 respectively (Table 6).

The competitive strengths, market, and aquaculture development positions of the aquaculture sectors of Egypt, Nigeria, Uganda, and South Africa are shown in Fig. 4. Egypt is located in the first quadrant, which depicts aquaculture development, competitive strengths and market opportunities. Nigeria is situated in the second quadrant, thus possessing aquaculture development and market opportunities but weak in competitive strengths. Nigeria $(0.250)$ has the highest aquaculture development and market opportunities compared to Egypt (0.114). Uganda is located in the third quadrant, therefore, possessing weak competitive strengths and confronted with low aquaculture development and market opportunities. South Africa is situated in the fourth quadrant, thus depicting competitive strengths but weak aquaculture development and market opportunities. Uganda demonstrates lesser aquaculture development and market threats $(-0.084)$ compared to South Africa (-0.279). South Africa (0.028), however, is competitively stronger than Uganda $(-0.060)$ and Nigeria $(-0.017)$ (Table 6 and Fig. 3).

The weighted mean values of internal and external SWOT assessment factors of the assessed countries are reported (Table 6). The mean weighted internal SWOT values of Egypt, Nigeria, Uganda, and South Africa were not significantly different (ANOVA LSD: df $3 ; p>$ 0.05 ) (Table 6). The mean weighted external SWOT values of Nigeria was significantly higher (ANOVA LSD: df $3 ; p<0.05$ ) than those of Uganda and South Africa, Egypt was significantly higher than South Africa (ANOVA LSD: df $3 ; p<0.05$ ). 


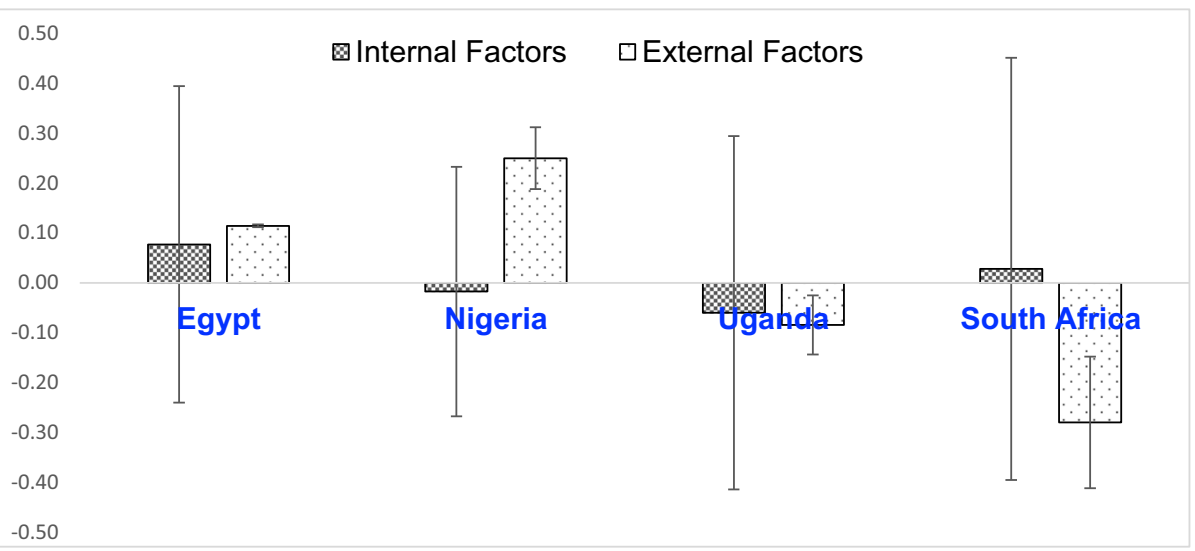

Fig. 3 Weighted internal and external SWOT assessment values of key African aquaculture players (Egypt, Nigeria, and Uganda) vis-à-vis South Africa

\section{Discussion}

Egypt was in quadrant I (Fig. 4), therefore possessing internal competitive strengths and economic opportunities for the development of its aquaculture sector. The distribution of its SWOT values was more skewed towards the opportunities and strengths axis, thus showing the potential to increase its aquaculture development opportunities and improve on the internal SWOT factors of its competitive aquaculture strengths. Egypt is the highest aquaculture producer (1.56 million tons) (FAO 2003-2020) in Africa and ranked sixth globally in 2018 due to the rapid development of its aquaculture sector. Egypt was able to leapfrog its aquaculture production from insignificant output to become one of the leading global aquaculture producers within two decades due to paradigm shift in the operating environment due to cumulative efforts and direct involvement of the government in the aquaculture sector (Cai et al. 2017; FAO 2003-2020). Egypt thus had continuously sustained its aquaculture production output from 71,815 tons in 1995 to 1.56 million tons in 2018. The burgeoning private sector participation and investment also aided the rapid expansion of the aquaculture industry (Shaalan et al. 2018). This led to the introduction of intensive pond aquaculture systems as a replacement for the extensive and semi-intensive aquaculture systems (FAO 2003-2020). The high returns on investment mainly drive the growth of intensive farming in Egypt. Egypt recorded the highest mean internal SWOT factor value mainly due to the scale of hatchery and seed production, cost of feed, research and development and economies of scale thus its production output (Table 4). Egypt has the highest concentration of hatcheries and seed production capacity in Africa. These includes 12 government-owned hatcheries, $\sim 100$ licensed privately operated hatcheries and over 500 unlicensed operational hatcheries; which account for the continued seed supply and competitive pricing (Macfadyen et al. 2012). Almost all the aquafeed in Egypt are locally produced; with a production capacity of $\sim 1$ million tons per year (El-Sayed et al. 2015). Aquafeeds are produced by both the governmentoperated and private operated feed mill with government feed mill accounting for about $20 \%$ of local production while $80 \%$ were from privately run feed mills (El-Sayed 2013). The combined local feed production capacity and competitive feed pricing are unmatched by any other African aquaculture sector. Key weaknesses limiting the aquaculture sector are limited and overstretched suitable land and inland water resources, which are in competitive use with 
Opportunities

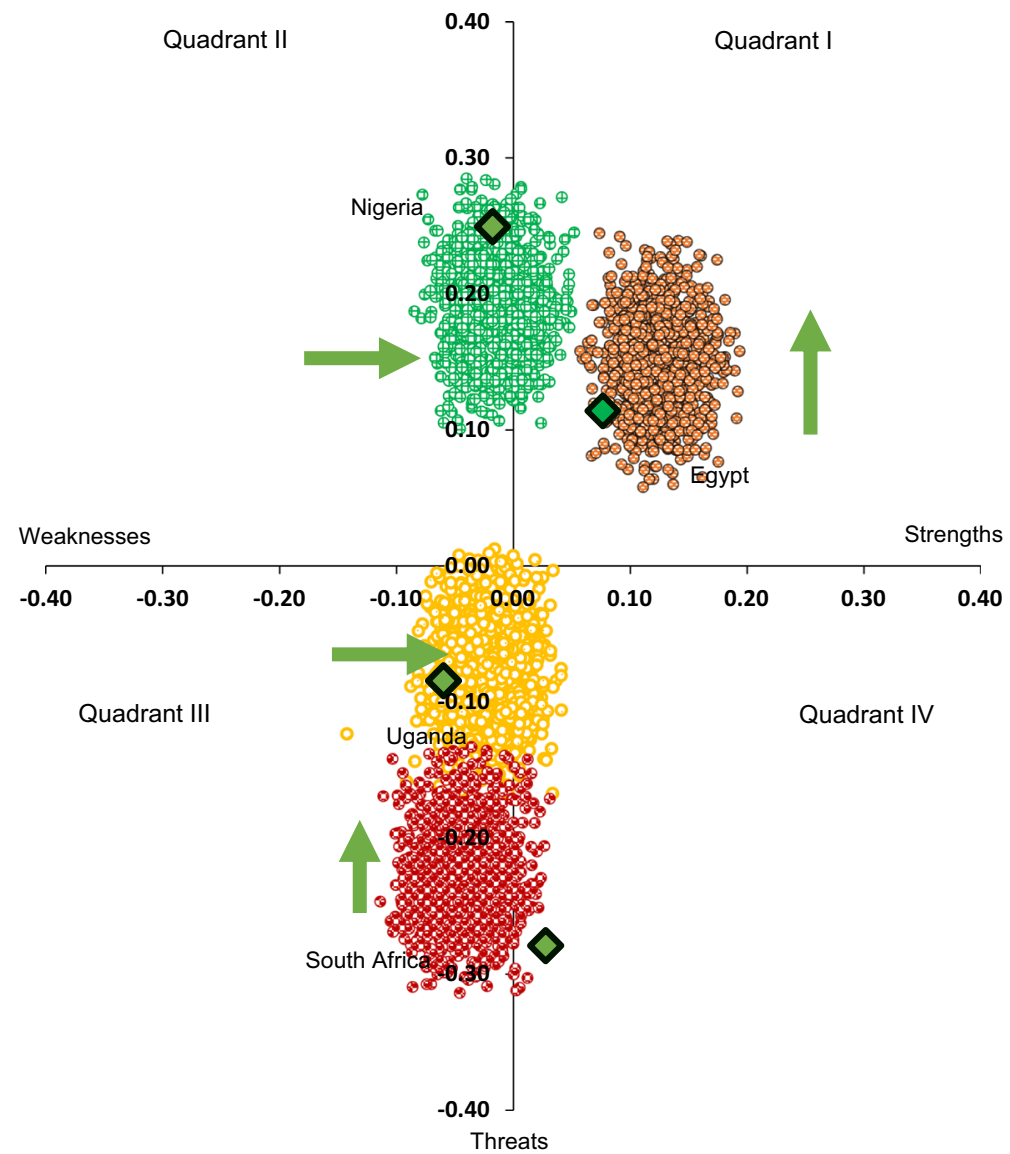

Fig. 4 Quantitative SWOT matrix performance of key African aquaculture players (Egypt, Nigeria, and Uganda) vis-à-vis South Africa

other agriculture and industrial activities (Soliman and Yacout 2016). These environmental limitations are also exacerbated by the impacts of climate change factors such as drought, flash floods, salinity changes, and sea-level rise. High per capita consumption of fish, the trade value of fish and provision of enabling environment for aquaculture development accounted for the high mean external SWOT assessment factor value of Egypt compared to Uganda and South Africa (Table 5). Fish, especially tilapia, is the most affordable source of animal protein and represent about 50\% of total animal protein intake in Egypt (Little et al. 2012; Cai et al. 2017). Egypt ranks second in Africa with the per capita fish consumption of $\sim 23.5 \mathrm{~kg}$ in 2017 after Ghana with a per capita fish consumption of $28 \mathrm{~kg}$ (Cai et al. 2017). Aquaculture policies, legislation and development models are implemented as government interventions in both human and institutional capacity as witnessed by the State's participation across the aquaculture value chain (Jamu et al. 2012). Egypt has also implemented strategic market-driven aquaculture development plans and legal framework to guide and protect investments in the industry (Jamu et al. 2012; Cai et al. 2017). Egypt is potentially positioned to strengthen its play in the global aquaculture market, if it adopts a bullish developmental strategy, such as 
international market penetration, aquaculture product development, and standardization which is currently a major threat confronting the sector.

Nigeria was situated in the second quadrant, meaning it has aquaculture development and economic opportunities to expand its aquaculture industry. Nigeria is however, confronted with some levels of weak competitive strengths. The distribution of its SWOT values showed that Nigeria has almost attained the peak of its aquaculture development potential based on the external SWOT factors considered in this study. The values were, however, slightly aligned towards the strength axis, thus showing some potentials to strengthen its competitive aquaculture strengths (Fig. 4). The significant opportunities for the Nigerian aquaculture industry stem from its high per capita fish consumption $(18.3 \mathrm{~kg}$ ) and widening fish demand-supply gap. Fish account for about $40 \%$ of animal protein consumed and are cheaper than other sources of animal protein (Cai et al. 2017). Relatively low aquaculture production output $(296,071)$ compared to total fish demand of about 3 million tons resulted in the vast fish demand-supply gap (WorldFish 2018). Although the widening demand-supply gap is partly offset by importation ( $~ 800,000$ tons) and capture fisheries ( 710,000 tons); an unbridged gap of about 1.5 million tons of fish still exist in the market (FAO 2007-2020). Nigeria is the largest importer of fish in Africa due to the massive importation of frozen fish averagely valued at $\$ 1$ billion per year (FAO 2007-2020). The enormous amount of money spent on fish importation annually can be substituted to expand domestic aquaculture production and value chain (Cai et al. 2017). Aquaculture policies, plan and legislation, are implemented as marketdriven aquaculture development interventions. This is to promote human capacity building, adaptive technologies required for efficient commercial aquaculture development and local economic development in Nigeria. The private sector primarily drives the aquaculture industry in Nigeria due to a policy shift towards commercialization of aquaculture (Obwanga et al. 2018). The government is saddled with the responsibility of providing enabling environment (Ozigbo et al. 2014; Adewumi 2015). Although the sector has a well-developed value-chain however, it is largely focused on catfish aquaculture (Cocker 2014; Obwanga et al. 2018). The internal competitive strengths such as abundance arable land distribution (1.7 million ha) and surface inland water (14 million ha) although currently under-utilized, can produce about 2.5 million tons of fish annually (FDF 2012). Over-dependence on single species (catfish) production at the expense of multi-species aquaculture development and the soaring cost of inputs are key weaknesses of the sector among others. To harness its vast market opportunities, Nigeria will need to maximize its area of competitive strength (developed catfish value chain; land and water availability; fish farming estates/clusters and R\&D) and improve on factors responsible for its weaknesses.

Uganda was in the third quadrant, indicating the aquaculture sector possesses lower competitive strengths compared to Egypt, South Africa, and Nigeria, and lesser market opportunities compared to Egypt and Nigeria (Fig. 4). Uganda is poised to strengthen its aquaculture development potential and market opportunities due to the distribution of its SWOT values being fairly skewed towards the strengths and along the opportunity axis. Fish is an essential source of animal protein and represent about $30 \%$ of animal protein intake in Uganda (Cai et al. 2017). The key threat confronting the aquaculture sector in Uganda is the weak institutional capacity (weak implementation of policies and frameworks) resulting in the poor enabling environment; thus, limiting the rapid development of aquaculture (FAO 20042020). Uganda is a landlocked country that is richly endowed with suitable land and the abundance of inland water resources (165 lakes) unlike Egypt and South Africa (Mulonde 2013) (see Table 1). The total aquaculture production output ( 103,737 tons 2018) vis-à-vis 
available land and water resources, however, portray gross under-utilization of its key competitive strengths. Ugandan's significant opportunity lies on the burgeoning local and export market for its fish products as significant quantities of the fish consumed in neighboring countries of Kenya, Democratic Republic of Congo, and South Sudan are imported from Uganda (Rutaisire et al. 2017). If the main threats of weak institutional capacity and inability to provide an enabling environment is therefore prioritized and promptly addressed by the government, this is expected to spur investment and commercial aquaculture development. Also, for Uganda to maximize its huge market opportunities, it will need to improve on factors responsible for its weaknesses and strengthen the areas of its competitive strengths.

South Africa was in the fourth quadrant, therefore, has more considerable competitive strengths, i.e., higher mean internal SWOT factor value (Fig. 4) compared to Uganda and Nigeria, notwithstanding, faces greater market and aquaculture development threats than all the compared countries. South African SWOT variables showed it had reached the peak of its internal SWOT factors of competitive aquaculture strengths; however, the values were aligned towards the opportunity axis; therefore, it has some levels of aquaculture development opportunities and market potential. South Africa scored relatively higher in the internal SWOT factors due to adoption of efficient aquaculture technology; culture of diverse freshwater and marine aquaculture species; good infrastructure and supporting business institution. South African aquaculture industry, however, is still nascent and performs below its potential in terms of production output (6181 tons) (FAO 2010-2020a). The major weaknesses of this sector are over-concentration on high-value abalone species with low production output ( 1513 tons), limited suitable land and overstretched inland water resources and suboptimal environmental conditions (Britz and Venter 2016). South Africa has a vast exposed shoreline at the southern part of Africa, with a heavy wave action due to the Southern Ocean frontal systems and Indian Ocean cyclones (FAO 2010-2020b). The potential for large-scale mariculture such as sea cage systems is, therefore, limited due to few sheltered bays of adequate size, along the coastline (Britz and Venter 2016).

Although the aquaculture sector has some promising opportunities such as access to international markets, good economic climate, sector prioritization by government, and development of enabling policies and frameworks, it is still highly threatened and limited by its external factors. The major combined threats plaguing the development of the aquaculture industry include but are not limited to complicated authorization processes, underdeveloped industry value chain, very low per capita fish consumption $(7 \mathrm{~kg})$, and scarce skilled resources (Mahieu 2015; IDC 2015). South Africa, unlike other African countries, has the most tedious aquaculture permit application process which is difficult for a prospective small/medium scale firm to attain, due to bureaucratic obstruction as regards environmental regulation compliance (IDC 2015). Therefore, over-regulation of the industry has been a significant threat and turnoff preventing the attraction of potential aquaculture investment and expansion. South Africa, on one hand, has well-developed national aquaculture policies and frameworks, unlike Nigeria and Uganda but, on the other hand, lacks a simplified aquaculture authorization procedure, unlike the other compared countries. Therefore, to fully maximize its internal strength and external opportunities in order to be well-positioned in the global aquaculture industry, South Africa will need to create a simplified one-stop-shop aquaculture authorization as well as aggressively promote the culture of eating fish to boost local demand. 


\section{Conclusion}

The aquaculture industry analysis of major players in Africa (Egypt, Nigeria, and Uganda) as against South Africa - an aspiring key player-was carried out using quantitative SWOT analyses. This study presents the first attempt at a quantitative comparative assessment of aquaculture sectors of key players in Africa by adopting a quantitative analytical business planning tool for aquaculture development. The study approach also forms a foundation that can be further developed for other quantified comparative analysis in fisheries management and aquaculture development studies. The study adopts both qualitative and quantitative comparative assessment of the aquaculture industry of the key players and South Africa through the evaluation of each country's SWOT (strengths, weakness, opportunities, and threats). SWOT analysis is a highly essential procedure adopted in the formulation of competitive strategy and developmental plan.

Limited accessibility to countries' data and updated records on the aquaculture sector constrained the availability of information database required for this study; hence the urgent need to bridge the gap on comprehensive aquaculture data in Africa.

The quantified SWOT analysis was used to determine the competitive position of the aquaculture sectors of the compared countries. It can be used as a basis for aquaculture policy and roadmaps. The position of Egypt in the SWOT quadrant places it in a better position than Nigeria, Uganda, and South Africa because of its competitive strengths and opportunities thus responsible for the development and production output of its aquaculture sector. Nigeria has the highest aquaculture development and market opportunities in Africa due to its huge demand-supply gap but needs to address its weaknesses in order to maximize its opportunities fully. Uganda's position indicates low, competitive strengths and market development opportunities; however, the Ugandan aquaculture sector faces minimal threats compared to South Africa. South Africa's aquaculture sector shows some levels of competitive strengths but with minimal market and aquaculture development opportunities due to combinations of internal and external SWOT factors such as sub-optimal environmental conditions, bottlenecked permitting processes, low per capita fish consumption, and others. The coordinate values of the quantified SWOT analysis of the compared countries thus reveal the individual country's aquaculture position in the regional competition and can also be adapted as a guide for developmental strategies.

Funding This research was supported by funding from NRF South Africa.

Data availability Main primary and secondary data used for this study are already included in tables inserted in the Methods section.

Code availability Not applicable

\section{Declarations}

Ethics approval This study does require either human or animal ethical clearance as primary and secondary data which do not qualify for ethical approval before the commencement of study were used.

Conflict of interest The authors declare no competing interests. 
Open Access This article is licensed under a Creative Commons Attribution 4.0 International License, which permits use, sharing, adaptation, distribution and reproduction in any medium or format, as long as you give appropriate credit to the original author(s) and the source, provide a link to the Creative Commons licence, and indicate if changes were made. The images or other third party material in this article are included in the article's Creative Commons licence, unless indicated otherwise in a credit line to the material. If material is not included in the article's Creative Commons licence and your intended use is not permitted by statutory regulation or exceeds the permitted use, you will need to obtain permission directly from the copyright holder. To view a copy of this licence, visit http://creativecommons.org/licenses/by/4.0/.

\section{References}

Adewumi A (2015) Aquaculture in Nigeria: sustainability issues and challenges. Direct Res J Agricult Food Sci $3: 12$

Ahmed N, Luong-Van J (2009) Can rice-fish farming provide food security in Bangladesh. Aquacult Asia 16(1): 23

Bolton J, Robertson-Andersson D, Shuuluka D, Kandjengo L (2009) Growing Ulva (Chlorophyta) in integrated systems as a commercial crop for abalone feed in South Africa: a SWOT analysis. J Appl Phycol 21(5):575583

Britz P, Venter S (2016) Aquaculture Review: South Africa. World Aquaculture, pp 20-28

Cai J, Quagrainie K, Hishamunda N (2017) Social and economic performance of tilapia farming in Africa. FAO Fisheries and Aquaculture Circular(C1130)

Çelik A, Metin İ, Çelik M (2012) Taking a photo of Turkish fishery sector: a SWOT analysis. Procedia Soc Behav Sci 58:1515-1524

Chang H-H, Huang W-C (2006) Application of a quantification SWOT analytical method. Math Comput Model 43(1-2):158-169

Cocker MLM (2014) Strategic review on African aquaculture markets and export potential, Partnership for African Fisheries (PAF) Aquaculture Working Group. University of Stirling/NEPAD Report

Cowx I, Arlinghaus R, Cooke S (2010) Harmonizing recreational fisheries and conservation objectives for aquatic biodiversity in inland waters. J Fish Biol 76(9):2194-2215

DAFF (2017) Aquaculture Yearbook 2016 South Africa. Department of Agriculture, Forestry and Fisheries Retrieved from http://www.nda.agric.za/doaDev/sideMenu/fisheries/03_areasofwork/Aquaculture/ AquaDocumentation/DAFF\%20Yearbook\%202016.5Mb.pdf

El-Sayed A (2007) Analysis of feeds and fertilizers for sustainable aquaculture development in Egypt. FAO Fisheries Technical Paper. 497:401.https://www.researchgate.net/publication/265886713_Analysis_of_ feeds_and_fertilizers_for_sustainable_aquaculture_development_in_Egypt. Accessed 20 May 2021

El-Sayed A-FM (2013) Tilapia feed management practices in sub-Saharan Africa, On-farm feeding and feed management in aquaculture. FAO Fisheries and Aquaculture Technical Paper(583), pp 377-405

El-Sayed A-FM, Dickson MW, El-Naggar GO (2015) Value chain analysis of the aquaculture feed sector in Egypt. Aquaculture 437:92-101

Fagbenro OA, Adebayo OT (2005) A review of the animal and aquafeed industries in Nigeria. A synthesis of the formulated animal and industry in sub-Saharan Africa, 25-36. http://www.fao.org/3/a0042e/a0042e05.htm\# bm5. Accessed 20 May 2021

FAO. (2003-2020). National Aquaculture Sector Overview. Egypt. National Aquaculture Sector Overview Fact Sheets. Text by Salem, A.M.; Saleh, M.A. In: FAO Fisheries and Aquaculture Department [online]. Rome. Updated 16 November 2010. [Cited 11 May 2020]. Retrieved from http://www.fao.org/fishery/ countrysector/naso_egypt/en

FAO. (2004-2020). Fishery and Aquaculture Country Profiles. Uganda (2004). Country Profile Fact Sheets. In: FAO Fisheries and Aquaculture Department [online]. Rome. Updated 1 December 2004. [Cited 25 May 2020]. http://www.fao.org/fishery/. Retrieved from http://www.fao.org/fishery/

FAO (2007-2020). Fishery and Aquaculture Country Profiles. Nigeria (2007). Country Profile Fact Sheets. In: FAO Fisheries and Aquaculture Department [online]. Rome. Updated 1 November 2017. [Cited 25 May 2020]. http://www.fao.org/fishery/. 
FAO. (2010-2020). Fishery and Aquaculture Country Profiles. South Africa (2018). Country Profile Fact Sheets. In: FAO Fisheries and Aquaculture Department [online]. Rome. Updated 1 May 2010. [Cited 13 May 2020]. http://www.fao.org/fishery/.

FAO. (2010-2020). National Aquaculture Sector Overview. South Africa. National Aquaculture Sector Overview Fact Sheets. Text by K. Halley and B. Semoli. In: FAO Fisheries and Aquaculture Department [online]. Rome. Updated 2010. [Cited 25 May 2020]. Retrieved from www.fao.org/fishery/countrysector/naso_ southafrica/en

FAO (2016) The state of World Fisheries and Aquaculture 2016. Contributing to food security and nutrition for all. Rome. $200 \mathrm{pp}$

FAO. (2018). The State of World Fisheries and Aquaculture 2018-Meeting the sustainable development goals. In: FAO Rome, Italy.

FAO. (2020). The State of World Fisheries and Aquaculture 2020. Sustainability in action. Rome. https://doi.org/ $10.4060 / \mathrm{ca} 9229 \mathrm{en}$.

FDF (2012) FDF, Federal Department of Fisheries (2012), 5th edn. Fisheries Statistics of Nigeria, pp 2008-2012

Garza-Gil MD, Varela-Lafuente M, Caballero-Miguez G (2009) Price and production trends in the marine fish aquaculture in Spain. Aquac Res 40(3):274-281

Glass JR, Kruse GH, Miller SA (2015) Socioeconomic considerations of the commercial weathervane scallop fishery off Alaska using SWOT analysis. Ocean Coast Manag 105:154-165

Görener A, Toker K, Ulucay K (2012) Application of combined SWOT and AHP: a case study for a manufacturing firm. Procedia Soc Behav Sci 58:1525-1534

Halwart, M. (2020). Fish farming high on the global food system agenda in 2020. FAO Aquaculture Newsletter(61), II-III.

IDC. (2015). Research into the potential for the production, processing and export of tilapia for the southern African market. https://www.idc.co.za/wp-content/uploads/2018/11/Tilapia-Research-Report-2015.pdf.

Jamu D, Brummett R (2004). Opportunities and challenges for African aquaculture. Use of genetically improved and alien species for aquaculture and conservation of aquatic biodiversity in Africa, 68:1

Jamu D, Chapotera M, Chinsinga B (2012) Synthesis of aquaculture policy and development approaches in Africa. WorldFish

Kurttila M, Pesonen M, Kangas J, Kajanus M (2000) Utilizing the analytic hierarchy process (AHP) in SWOT analysis - a hybrid method and its application to a forest-certification case. Forest Policy Econ 1(1):41-52

Little, D. C., Barman, B. K., Belton, B., Beveridge, M. C., Bush, S. J., Dabaddle, L., . . . Kibria, G. (2012). Alleviating poverty through aquaculture: progress, opportunities and improvements.

Macfadyen G, Nasr-Alla AM, Al-Kenawy D, Fathi M, Hebicha H, Diab AM et al (2012) Value-chain analysisan assessment methodology to estimate Egyptian aquaculture sector performance. Aquaculture 362:18-27

Mahieu A (2015) Fish-farming in South Africa: a study of the market environment and the suitable species (Doctoral dissertation, Stellenbosch: Stellenbosch University). Stellenbosch University, Stellenbosch

Mulonde, N. (2013). Nikumu fish farming project. Document for NFFP and IECEDAA. (also available at www. globalgiving. org/pfil/14495/projdoc. pdf).

Nassr-Alla A (2008) Egyptian aquaculture status, constraints and outlook. CIHEA M analytical notes, (32). http://portail2.reseau-concept.net/Upload/ciheam/fichiers/ANP32.pdf. Accessed 20 May 2021

Nasr-Allah AM, Dickson MW, Al-Kenawy DAR, Ahmed MFM, El-Naggar GO (2014) Technical characteristics and economic performance of commercial tilapia hatcheries applying different management systems in Egypt. Aquaculture 426:222-230

Obwanga, B., Rurangwa, E., van Duijn, A. P., Soma, K., \& Kilelu, C. (2018). A comparative study of aquaculture sector development in Egypt, Ghana and Nigeria: insights and lessons for Kenya. Retrieved from

Oyakhilomen O, Zibah RG (2013) Fishery production and economic growth in Nigeria: Pathway for sustainable economic development. J Sustain Develop Afr 15(2):11

Ozigbo E, Anyadike C, Adegbite OS, Kolawole P (2014) Review of aquaculture production and management in Nigeria. Am J Exper Agricult 4(10):1137-1151

Panigrahi JK, Mohanty PK (2012) Effectiveness of the Indian coastal regulation zones provisions for coastal zone management and its evaluation using SWOT analysis. Ocean Coast Manag 65:34-50

Phadermrod B, Crowder RM, Wills GB (2016) Importance-performance analysis based SWOT analysis. Int J Inf Manag

Radheyshyam N (2001) Community-based aquaculture in India-strengths, weaknesses, opportunities and threats. ICLARM Quart 1

Rimmer MA, Sugama K, Rakhmawati D, Rofiq R, Habgood RH (2013) A review and SWOT analysis of aquaculture development in Indonesia. Rev Aquac 5(4):255-279 
Rutaisire J, Nandi S, Sundaray J (2017) A review of Uganda and Indias freshwater aquaculture: key practices and experience from each country. J Ecol Nat Environ 9(2):15-29

Satia BP (2011) Regional review on status and trends in aquaculture development in sub-saharan africa - 2010/ Revue régionale sur la situation et les tendances dans l'aquaculture en afrique subsaharienne - 2010. FAO Fisheries and Aquaculture Circular, (C1061/4), I. - http://www.fao.org/3/i2261b/i2261b.pdf. Accessed 20 May 2021

Satia BP (2016) An overview of the large marine ecosystem programs at work in Africa today. Environ Dev 17: $11-19$

Satia, B. (2010). Aquaculture development in Africa: current status and future prospects.

Shaalan M, El-Mahdy M, Saleh M, El-Matbouli M (2018) Aquaculture in Egypt: insights on the current trends and future perspectives for sustainable development. Rev Fish Sci Aquacult 26(1):99-110

Soliman NF, Yacout DM (2016) Aquaculture in Egypt: status, constraints and potentials. Aquac Int 24(5):12011227

Stead SM (2005) Changes in Scottish coastal fishing communities - understanding socio-economic dynamics to aid management, planning and policy. Ocean Coast Manag 48(9-10):670-692

WorldFish. (2018). WorldFish Nigeria Strategy: 2018-2022. Penang, Malaysia: WorldFish. Strategy: 2018-09. Retrieved from https://www.worldfishcenter.org/country-pages/nigeria

Publisher's note Springer Nature remains neutral with regard to jurisdictional claims in published maps and institutional affiliations. 